\title{
PERBEDAAN HASIL BELAJAR SISWA MENGGUNAKAN MODEL PEMBELAJARAN KOOPERATIF TIPE JIGSAW DENGAN TIPE STUDENT TEAM ACHIEVEMENT DIVISION (STAD) PADA MATERI SISTEM ENDOKRIN MANUSIA
}

\author{
Aspatita Yuliani Panjaitan ${ }^{1}$, Erlintan Sinaga ${ }^{1}$, Rasmi $^{2}$ \\ ${ }_{1}^{1}$ Program Studi Pendidikan Biologi, FMIPA, Universitas Negeri Medan, Jl. Willem Iskandar Psr. V Medan Estate, \\ Medan, Indonesia, 20221 \\ 2 SMAN 7 Medan, Jl. Timor No. 36, Kelurahan Gaharu, Kecamatan Medan Timur, Sumatera Utara, 20235 \\ *Korespondensi Author: titayuliani56@yahoo.com
}

\section{INFOARTIKEL}

Histori Artikel

Received 24 Januari 2019

Revised 26 Maret 2020

Accepted 26 Maret 2020

Published 2 April 2020

Keywords:

Students' learning result, students' activities, Jigsaw model, STAD model

\begin{abstract}
ABSTRAK
Penelitian ini bertujuan untuk mengetahui perbedaan hasil belajar siswa yang diajarkan dengan model pembelajaran kooperatif tipe Jigsaw dan STAD (Student Team Achievement Division) pada materi sistem endokrin manusia di kelas XI MIA SMA Negeri 7 Medan T.P. 2017/2018. Jenis penelitian ini adalah penelitian eksperimen. Populasi penelitian terdiri dari 72 orang dan teknik pengambilan sampel dengan cara random sampling, dimana kelas XI MIA 1 (kelas Jigsaw) sebanyak 36 orang, dan kelas XI MIA 2 (kelas STAD) sebanyak 36 orang. Alat yang digunakan dalam pengumpulan data berupa tes yang berbentuk soal pilihan berganda terdiri dari 30 butir soal dan lembar observasi aktivitas siswa. Berdasarkan analisis data bahwa nilai rata-rata hasil belajar model pembelajaran Jigsaw sebesar 84,84 dengan SD 9,06 dan hasil belajar model STAD sebesar 79,88 dengan SD 8,96. Dari data yang diperoleh diketahui bahwa nilai rata-rata kelas Jigsaw lebih tinggi dibandingkan kelas STAD. Hasil pengujian hipotesis dengan menggunakan uji-t pada taraf signifikan 0.05, dapat kedua kelas berbeda signifikan.
\end{abstract}

\section{ABSTRACT}

This research is aimed to know the difference of students' learning scores who were taught by using cooperative Jigsaw dan STAD (Student Team Achievement Division) model in the endocrine system of human body material in grade XI MIA SMA Negeri 7 Medan year of academic 2017/2018. This research is design as an experimental. The population of this research is 72 students, and the sample was taken by random sampling, which XI IPA 1 class (as Jigsaw class) there are 36 students and XI IPA 2 class (as STAD class) there are 36 students. The data is collected by using a multiple-choice question test consist of 30 items and an observation sheet. Based on the analysis requirements data, the average value of students' learning scores in the Jigsaw model at 84,84 with SD 9,06 and students' learning scores in the STAD model at 79,88 with SD 8.96 . From the data obtained it is known that the average value of the Jigsaw class is higher than the STAD class. The results of hypothesis testing using t-test at a significant level of 0.05 , can the two classes differ significantly.

Copyright @ 2019 Universitas Negeri Medan. Artikel Open Access dibawah lisensi CCBY-4.0 (https://creativecommons.org/licenses/by/4.0) 


\section{How To Cite:}

Panjaitan, A. W., SInaga, E., \& Rasmi. (2020). Perbedaan Hasil Belajar Siswa Menggunakan Model Pembelajaran Kooperatif Tipe Jigsaw Dengan Tipe Student Team Achievement Division (STAD) Pada Materi Sistem Endokrin Manusia. Jurnal Pelita Pendidikan, 8(1), 020-021.

\section{PENDAHULUAN}

Pendidikan adalah suatu usaha sadar dan terencana untuk mengembangkan kemampuan, kompetensi, dan kepribadian sehingga mampu menempatkan manusia dalam derajat yang terbaik dalam kehidupannya (Achrudin dkk, 2013). Salah satu masalah yang dihadapi dunia pendidikan Indonesia saat ini adalah lemahnya proses pembelajaran. Proses pembelajaran di kelas lebih diarahkan kepada kemampuan anak untuk menghafal informasi. Anak dipaksa untuk mengingat dan menimbun informasi tanpa dituntut untuk memahami informasi yang diingatnya dan menghubungkannya dengan kehidupan sehari-hari. Akibatnya terjadi akumulasi pengetahuan pada anak didik tanpa dibarengi aplikasi dan keterampilan. Permasalahan ini disebabkan oleh proses belajar-mengajar yang masih belum tepat (Trianto, 2016).

Menurut Marrysca, dkk (2013), banyak faktor yang memengaruhi kemampuan dan keberhasilan peserta didik dalam memahami suatu materi pelajaran dari hasil belajarnya, salah satunya adalah penggunaan model pembelajaran. Kenyataannya, masih banyak pendidik yang belum menerapkan pembelajaran yang mengacu pada standar proses pendidikan tersebut. Pembelajaran TCL (Teacher Centered Learning) masih banyak diterapkan dalam proses pembelajaran di kelas karena dianggap praktis dan tidak banyak menyita waktu. Guru menyajikan materi secara teoritis dan abstrak sedangkan siswa cenderung pasif. Akibat dari kebiasaan tersebut siswa menjadi kurang kreatif dalam memecahkan masalah, partisipasi rendah, kerja sama dalam kelompok tidak optimal, kegiatan belajar mengajar tidak efisien dan pada akhirnya hasil belajar menjadi rendah.

Berdasarkan pengamatan dan wawancara yang penulis lakukan pada bulan April tahun 2018 dengan guru mata pelajaran biologi di SMA Negeri 7 Medan, bahwa guru sudah menggunakan metode tanya jawab dalam proses pembelajaran tetapi lebih dominan metode ceramah. Metode ceramah ini menyebabkan siswa cenderung malas bertanya, tidak fokus dalam mata pelajaran yang disampaikan karena tidak adanya variasi guru dalam menyampaikan pelajaran. Hal ini dapat dilihat dari antusias siswa dalam mempelajari materi pelajaran biologi sangat kurang, mereka kurang peduli terhadap materi yang disampaikan oleh guru tersebut. Sehingga ketika guru mengadakan ulangan banyak siswa yang tidak dapat menjawab soal sehingga menyebabkan hasil belajar siswa rendah. Hasil belajar kognitif siswa cenderung masih di bawah nilai batas tuntas yakni rata-rata 65 dengan KKM 75. Dari fakta tersebut diketahui bahwa guru belum terbiasa menggunakan model pembelajaran yang bisa membuat siswa menjadi tertarik terhadap materi yang diajarkan guru.

Pembelajaran sistem endokrin manusia merupakan sub-materi dari sistem koordinasi selain dua (2) sub-materi lainnya, yatu sistem saraf dan sistem indera. Sistem endokrin merupakan materi yang cukup sulit karena materi tersebut masih bersifat abstrak. Menurut Regia, dkk (2014), berdasarkan observasi yang dilakukan di SMAN 1 Lawang menunjukkan $73,3 \%$ siswa dan $66 \%$ guru menyatakan kesulitan pada pembelajaran materi sistem endokrin manusia. Kesulitan ini disebabkan oleh beberapa faktor, salah satunya yaitu materi sistem endokrin manusia yang sulit dan abstrak.

Berdasarkan uraian di atas, terjadi kesenjangan antara pembelajaran Biologi yang ideal dan kenyataan di sekolah dikarenakan model yang digunakan guru untuk mengajar tidak mendorong siswa menggali pengetahuannya sendiri. Oleh karena itu, perlu adanya perubahan yang dilakukan oleh guru, yaitu dengan menggunakan model pembelajaran kooperatif. Menurut Johnson \& Johnson, 2008: Slavin, 2011, pembelajaran kooperatif adalah salah satu jenis pendekatan pembelajaran yang berpusat pada siswa, banyak literatur yang mendokumentasikan bahwa pendekatan ini efektif dan kemampuan dalam hal pemahaman pengetahuan, dan mempromosikan sikap positif siswa terhadap pembelajaran mereka sendiri. Pembelajaran kooperatif merupakan pembelajaran yang 
mengharuskan siswa bekerja dalam suatu kelompok untuk menyelesaikan masalah, atau mengerjakan tugas untuk tujuan bersama (Sanjaya, 2008).

Dari beberapa model pembelajaran kooperatif yang ada, penulis memilih model pembelajaran kooperatif tipe Jigsaw dan pembelajaran kooperatif tipe STAD (Student Team Achievment Division) untuk digunakan pada penelitian ini. Dalam Arend,R.I. (2001), pembelajaran kooperatif tipe Jigsaw merupakan salah satu model pembelajaran inovatif yang dapat membawa siswa pada suasana belajar yang lebih aktif, karena pembelajaran Jigsaw menggabungkan kegiatan membaca, menulis, mendengarkan dan berbicara. Model pembelajaran kooperatif tipe Jigsaw merupakan model pembelajaran kooperatif, dengan siswa belajar dalam kelompok kecil yang terdiri dari 4-6 orang secara heterogen dan bekerjasama saling ketergantungan yang positif dan bertanggung jawab atas ketuntasan bagian materi pelajaran yang harus dipelajari dan menyampaikan materi tersebut kepada anggota kelompok yang lain (Novianti, 2012). Model pembelajaran kooperatif tipe Jigsaw didesain untuk meningkatkan rasa tanggung jawab siswa terhadap pelajarannya sendiri dan juga pembelajaran orang lain.

Dalam Slavin (2011), model pembelajaran tipe Student Teams Achievement Division (STAD) merupakan model pembelajaran yang bersifat diskusi berkelompok yang mendorong peserta didik untuk berani mengemukakan pendapat, dan mengambil kajian dari kegiatan belajar. Model pembelajaran tipe Student Teams Achievement Division (STAD) merupakan model pembelajaran kooperatif yang paling sederhana dan mudah diterapkan diantara beberapa model pembelajaran kooperatif yang lain, sehingga model ini sangat cocok bagi guru pemula yang belum terbiasa dengan metode pembelajaran kooperatif. STAD efektif untuk meningkatkan motivasi belajar siswa, karena STAD mengedepankan struktur penghargaan sebagai bentuk penguatan (reinforcement) terhadap apa yang telah dilakukan oleh siswa. Penghargaan tersebut dapat meningkatkan motivasi belajar siswa.
Mengacu pada paparan tentang latar belakang masalah di atas maka peneliti melakukan penelitian perbedaan hasil belajar dan aktivitas belajar siswa menggunakan model pembelajaran kooperatif tipe jigsaw dengan tipe student team achievment division (stad) pada materi sistem endokrin di Kelas XI IPA SMA Negeri 7 Medan T.P 2017/2018.

\section{METODE PENELITIAN}

Penelitian ini dilaksanakan di SMA Negeri 7 Medan yang beralamat di Jl. Timor No. 36 Kecamatan Medan Timur, Medan Sumatera Utara SMA, Negeri 7, Medan. Populasi pada penelitian ini adalah seluruh siswa kelas XI MIA SMA Negeri 7 Medan TP. 2017/2018 sebanyak 6 kelas yang berjumlah 233 orang. Sampel pada penelitian ini adalah Kelas XI MIA 1 sebagai kelas Jigsaw dan Kelas XI MIA 2 sebagai kelas STAD yang berjumlah 72 siswa dengan teknik Random sampling. Instrumen penelitian ini yaitu tes objektif berbentuk pilihan berganda sebanyak 30 soal sebagai soal pretes dan postes yang sebelumnya dilakukan uji validasi soal,uji reliabilitas, uji daya beda dan tingkat kesukaran soal.

\section{HASIL DAN PEMBAHASAN}

Dari hasil pretes diketahui nilai rata-rata pada kelas Jigsaw sebesar 36,3 sedangkan, pada kelas STAD diketahui nilai rata-rata siswa sebesar 35,54. Sedangkan hasil postes diketahui nilai rata-rata siswa kelas Jigsaw sebesar 84,84 dan pada kelas STAD diperoleh nilai rata-rata sebesar 79,88 . Berikut merupakan perbedaan nilai postest pada kelas Jigsaw dan STAD (Tabel 1 dan Gambar 1).

Berdasarkan Tabel 1 dan Gambar 1 diketahui bahwa kedua kelas dinyatakan tuntas secara keseluruhan karena nilai rata-rata di atas nilai KKM yaitu 75. Rata-rata postest hasil belajar siswa kelas model kooperatif tipe Jigsaw $(84,84)$ lebih tinggi dibandingkan dengan rata-rata postest hasil belajar siswa kelas model kooperatif tipe $\operatorname{STAD}(79,88)$. Nilai postes terendah pada kelas Jigsaw adalah 63,3 dan kelas STAD adalah 66,6, sedangkan nilai postes tertinggi pada kelas Jigsaw dan STAD adalah 96,6. 
Tabel 1. Perbedaan nilai Postest Kelas Jigsaw dan STAD

\begin{tabular}{|c|c|c|c|c|c|c|c|c|c|}
\hline \multicolumn{5}{|c|}{ Kelas Jigsaw } & \multicolumn{5}{|c|}{ Kelas STAD } \\
\hline Nilai & $\mathrm{F}$ & $\bar{X}$ & $S^{2}$ & SD & Nilai & $\mathrm{F}$ & $\bar{X}$ & $S^{2}$ & SD \\
\hline 63,3 & 2 & \multirow{11}{*}{84,848} & \multirow{11}{*}{82,33} & \multirow{11}{*}{9,06} & 66,6 & 3 & \multirow{11}{*}{79,88} & \multirow{11}{*}{80,35} & \multirow{11}{*}{8,96} \\
\hline 66,6 & 1 & & & & 70 & 6 & & & \\
\hline 70 & 3 & & & & 73,3 & 4 & & & \\
\hline 73,3 & 6 & & & & 76,6 & 3 & & & \\
\hline 76,6 & 4 & & & & 80 & 6 & & & \\
\hline 80 & 4 & & & & 83,3 & 2 & & & \\
\hline 83,3 & 1 & & & & 86,6 & 3 & & & \\
\hline 86,6 & 4 & & & & 90 & 5 & & & \\
\hline 90 & 6 & & & & 93,3 & 3 & & & \\
\hline 93,3 & 4 & & & & 96,6 & 1 & & & \\
\hline 96,6 & 1 & & & & & & & & \\
\hline Jumlah & 36 & & & & Jumlah & 36 & & & \\
\hline
\end{tabular}

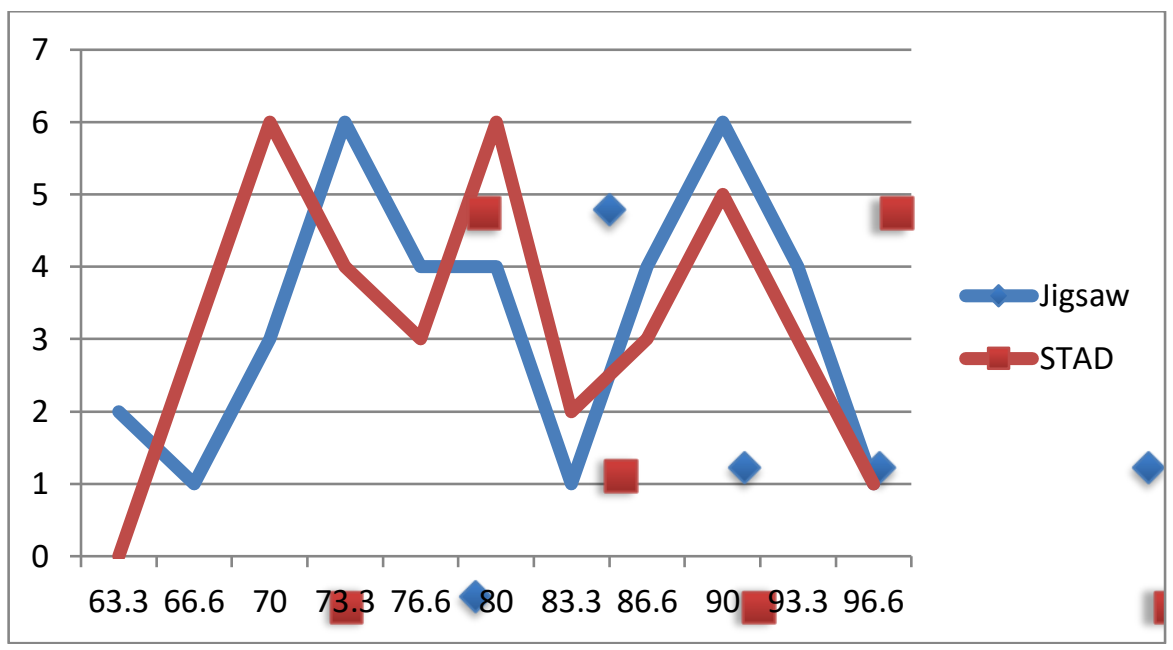

Gambar 1. Grafik Perbedaan Postest Kelas Jigsaw dan STAD

Uji prasyarat analisis data dilakukan dengan uji normalitas, uji homogenitas dan uji hipotesis. Uji normalitas data penelitian menggunakan uji Liliefors dengan taraf signifikan $5 \%(\alpha=0,05)$. Syarat normal dipenuhi jika Lhitung < Ltabel. Hasil perhitungan uji normalitas, data penelitian secara ringkas diperlihatkan pada Tabel 3.
Uji homogenitas data penelitian dilakukan dengan uji $\mathrm{F}$ yang terdapat pada Tabel 3. Uji hipotesis dilakukan melalui uji $\mathrm{t}$, dengan taraf signifikan $\alpha=0,05$ (Tabel 4.) dapat diketahui bahwa $t_{\text {hitung }}>t_{\text {tabel }}$ yaitu 2,39 > 1,67 maka, Ha diterima dan Ho ditolak yang berarti ada perbedaan hasil belajar siswa pada model pembelajaran kooperatif tipe Jigsaw dengan tipe STAD pada materi sistem endokrin manusia di kelas XI MIA Negeri 7 Medan Tahun T.P. 2017/2018. 
Tabel 2. Hasil Analisis Uji Normalitas Data Penelitian

\begin{tabular}{cccccc}
\hline No & Data & Kelas & Lhitung & Ltabel $(\alpha=0.05)$ & Kesimpulan \\
\hline 1 & Pretes & Jigsaw & 0,0915 & 0,1476 & Normal \\
2 & Pretes & STAD & 0,1209 & 0,1476 & Normal \\
3 & Postes & Jigsaw & 0,9555 & 0,1476 & Normal \\
4 & Postes & STAD & 0,1297 & 0,1476 & Normal \\
\hline
\end{tabular}

Tabel 3. Hasil Perhitungan Uji Homogenitas Data Penelitian

\begin{tabular}{ccccccc}
\hline No & Data & Kelas & Varians & Fhitung & Ftabel & Kesimpulan \\
\hline \multirow{2}{*}{1} & \multirow{2}{*}{ Pretes } & Jigsaw & 64,97 & \multirow{2}{*}{1,098} & \multirow{2}{*}{1,77} & Homogen \\
& & STAD & 71,46 & & & Homogen \\
\multirow{2}{*}{2} & \multirow{2}{*}{ Postes } & Jigsaw & 92,33 & \multirow{2}{*}{1,10} & 1,77 & Homogen \\
& & STAD & 90,47 & & & Homogen \\
\hline
\end{tabular}

Tabel 4. Hasil Uji Hipotesis Data Penelitian

\begin{tabular}{ccccccc}
\hline Kelas & Rata-rata & $\mathbf{n}$ & Varians & $\mathbf{t}_{\text {hitung }}$ & $\mathbf{t}_{\text {tabel }}$ & Keterangan \\
\hline Jigsaw & 82,76 & 36 & 26,43 & 2,63 & 1,67 & Ha diterima \\
STAD & 79,34 & 36 & 34,44 & 2,63 & &
\end{tabular}

Penelitian ini menggunakan dua kelas sampel yang diberikan dua perlakuan berbeda dimana kelas XI IPA 1 diajar menggunakan model kooperatif tipe Jigsaw dan kelas XI MIA 2 diajar menggunakan model kooperatif tipe Student Team Achievement Division (STAD). Instrument penelitian berupa tes pilihan berganda yang digunakan setelah kedua kelas diajar (postes) dengan model kooperatif Jigsaw dan STAD. Dari hasil penelitian yang telah dilakukan dapat disimpulkan bahwa hasil belajar siswa dengan menggunakan model kooperatif tipe Jigsaw lebih tinggi dari pada model kooperatif tipe STAD pada materi Sistem Endokrin Manusia di Kelas XI MIA SMA Negeri 7 Medan T.P. $2017 / 2018$. Berdasarkan hasil pengamatan di kelas Jigsaw, siswa cenderung lebih aktif untuk saling berdiskusi, bertanya, kemudian mengumpulkan informasi yang dilakukan secara berkelompok dikelompok ahli masing-masing. Siswa saling bekerjasama untuk berdiskusi untuk mencari jawaban yang tertera pada lembar LKPD yang telah diberikan oleh guru dan berbagi ilmu. Pada sistem pembagian kelompok ditentukan secara acak, jadi didalam suatu kelompok terdapat kemampuan siswa yang berbeda-beda pula.

Pada pelaksanaannya, model pembelajaran tipe Jigsaw memiliki dua jenis kelompok, yaitu kelompok ahli dan kelompok asal. LKPD yang telah dibagikan oleh pendidik kepada setiap kelompok didiskusikan secara bersama-sama di kelompok ahli. Setiap kelompok memiliki subtopik pembahasan yang berbeda. Setelah informasi yang diperlukan sudah didapat dan waktu yang diberikan untuk berdiskusi telah usai, seluruh siswa membentuk kelompok asalnya masing-masing untuk mendiskusikan dan membagiakan informasi yang telah diperolehnya dari berdiskusi dengan kelompok ahli kepada semua anggota kelompok asalnya. Model pembelajaran tipe Jigsaw membentuk siswa untuk memotivasi diri. Hal ini dikarenakan pada model pembelajaran kooperatif tipe Jigsaw setiap anggota kelompok ahli yang sudah mendiskusikan dan mengumpulkan informasi harus membagikannya kepada anggota kelompok asalnya. Hal ini mengakibatkan setiap peserta didik harus serius dalam berdiskusi di dalam kelompok ahlinya masing-masing. Setelah semua anggota kelompok asal membagikan informasi yang telah diperolehnya, pendidik dapat menguji pengetahuan peserta didik. Hal ini juga yang semakin memotivasi peserta didik untuk tekun dan serius saat berdiskusi (Roviati, 2012).

Dari hasil penelitian yang telah dilaksanakan, bahwa metode pembelajaran kooperatif tipe Jigsaw di kelas XI MIA 1, siswanya lebih mudah dalam memahami materi pelajaran dikarenakan model pembelajaran Jigsaw membuat pelajaran menjadi lebih menarik dan meningkatkan kemampuan berpikir secara mendalam dan kemampuan analisis secara kritis (Alsa, 2010). Hal ini sejalan dengan Johnson \& Johnson, 2008: Slavin, 2011 bahwa pembelajaran kooperatif dapat meningkatkan hasil belajar siswa dikarenakan pembelajarazn berpusat pada siswa, dan efektif membantu siswa dalam pengembangan kemampuan, komunikasi, dan untuk mengembangkan pengetahuan.

Karena, pada kelas Jigsaw, setelah guru menjelaskan mengenai materi pelajaran, maka siswa berkumpul dan membentuk kelompok ahli. 
Secara berkelompok, setiap anggota kelompok ahli mendiskusikan LKPD yang telah diberikan oleh guru. Setelah selesai mendiskusikan LKPD, setiap anggota kelompok ahli kembali ke kelompok asalnya untuk membagikan informasi yang telah diperoleh kepada teman sekelompok asalnya. Setelah waktu yang diberikan oleh guru telah usai, guru dapat menguji pengetahuan peserta didik yang sudah berdiskusi sebelumnya. Hal inilah yang memicu anak untuk memotivasi dirinya untuk serius saat berdiskusi dengan teman sekelompoknya. Menurut Yulaikah (2012), Model Pembelajaran Kooperatif tipe Jigsaw dapat meningkatkan hasil belajar siswa. Hal ini sejalan dengan penelitian yang dilakukan oleh Tran dan Lewis (2012), pembelajaran kooperatif tipe Jigsaw membuat siswa bekerja dalam kelompok dan saling membantu (kerjasama), diskusi dan berbagi informasi dan belajar bersama, dan membuat pembelajaran menjadi menyenangkan.

Dibandingkan dengan model pembelajaran kooperatif tipe Jigsaw, model STAD juga bersifat diskusi kelompok, hanya saja dibandingkan model Jigsaw yang memiliki kelompok asal dan kelompok ahli, model STAD hanya bersifat diskusi saja. Namun, dalam praktiknya model STAD merupakan model pembelajaran kooperatif yang paling sederhana dan paling mudah untuk diaplikasikan oleh guru yang belum terbiasa menggunakan model pembelajaran kooperatif sebelumnya. Hal ini yang menyebabkan siswa pada kelas Jigsaw lebih memahami mengenai materi pelajaran daripada kelas STAD yang terlihat pada nilai postes yang dilakukan, yaitu pada kelas Jigsaw nilai rata-rata postes adalah 81,36 sedangkan, pada kelas STAD nilai rata-rata postes adalah 79,86 .

Dari hasil penelitian yang dilakukan, pada dasarnya penerapan model pembelajaran kooperatif tipe Jigsaw dan STAD ini memberikan dampak positif berupa peningkatan hasil belajar siswa dan juga aktivitas belajar siswa. Hal ini di karenakan kedua model ini memberikan suasana yang menyenangkan bagi siswa, yaitu pada kelas Jigsaw, dengan adanya kelompok asal dan kelompok ahli, siswa menjadi lebih termotivasi dalam mengumpulkan informasi yang dibutuhkan untuk menjawab LKPD, sedangkan kelas STAD akan menerima reward bagi kelompok dengan prestasi terbaik, mendorong siswa untuk lebih aktif dan bersemangat di kelas,, hal ini sesuai dengan penelitian Hasan, $d k k$ (2016). Selain itu, kedua model ini melatih siswa untuk terampil dalam berbicara, mengolah informasi dan berdiskusi dalam kelompok. Namun keberhasilan kedua model ini tidak lepas dari keterampilan guru dalam mengajar dan mengelola kelas serta kesesuaiannya dengan materi yang diajarkan. Pada penelitian ini dilakukan pengujian hipotesis untuk kelas model Jigsaw dan kelas model STAD dengan menggunakan uji-t. Setelah dilakukan pengujian data, ternyata diperoleh bahwa $t_{\text {hitung }}>t_{\text {tabel }}(4,25>1,62)$. Hal ini berarti bahwa $\mathrm{H}_{\mathrm{o}}$ ditolak dan $\mathrm{H}_{\mathrm{a}}$ diterima yang berarti terdapat perbedaan hasil belajar dengan menggunakan model pembelajaran kooperatif tipe Jigsaw dengan STAD (Student Team Achievement Division) pada materi sistem endokrin manusia di kelas XI MIA SMA Negeri 7 Medan T.P. 2017/2018.

\section{KESIMPULAN}

Hasil belajar siswa dengan pembelajaran model kooperatif tipe Jigsaw (nilai rata-rata 84,84) lebih tinggi daripada hasil belajar siswa dengan pembelajaran model kooperatif tipe STAD (Student Team Achievement Division) (nilai rata-rata 79,88) pada materi sistem endokrin manusia di kelas XI MIA SMA Negeri 7 Medan T.P. 2017/2018 dan terdapat perbedaan yang signifikan antara hasil belajar siswa menggunakan pembelajaran model kooperatif tipe Jigsaw dengan STAD (Student Team Achievement Division) pada materi sistem endokrin manusia di kelas XI MIA SMA Negeri 7 Medan T.P. 2017/2018 pada $\alpha=0,05$.

\section{UCAPAN TERIMA KASIH}

Terima kasih kepada SMA Negeri 7 Medan memberikan izin dalam penelitian ini.

\section{DAFTAR PUSTAKA}

Achrudin, A., Sajidan, S., \& Indrowati, M. (2013). Peningkatan Aktivitas Sosial Siswa dalam Pembelajaran Biologi melalui Penerapan Model Pembelajaran STAD disertai Video di Kelas VII SMP Negeri 1 Jaten. Pendidikan Biologi, 5(1).

Alsa, A. (2010). Pengaruh metode belajar Jigsaw terhadap keterampilan hubungan interpersonal dan kerjasama kelompok pada mahasiswa fakultas psikologi. Jurnal Psikologi, 37(2), 165-175.

Arend,R.I, S., (2010), Dasar-dasar Evaluasi Pendidikan, Penerbit Aksara: Jakarta.

Hasan, S., Kasuba, F. T., \& Sirajudin, N. (2016). Penerapan Pembelajaran Model Student Teams Achivement Division (STAD) Untuk Meningkatkan Hasil Belajar dan Aktivitas Siswa Kelas VII Pada Konsep Ekosistem di SMP Negeri 6 Bibinoi. BIOEDUKASI, 4(2).

Novianti, I. (2012). Eksperimentasi Model 
Pembelajaran Kooperatif Tipe STAD dan Jigsaw pada Pokok Bahasan Sistem Persamaan Linear Dua Variabel Ditinjau dari Motivasi Belajar. Jurnal Pendidikan, 13(1), 23-31.

Marrysca, A. F. V., Surantoro, S., \& Ekawati, E. Y. (2013). Penerapan Model Pembelajaran Kooperatif Tipe Stad (Student Teams Achievement Divisions) berbantuaan Lks (Lembar Kerja Siswa) Berkarakter Untuk Meningkatkan Aktivitas Belajar Dan Kemampuan Kognitif Fisika Siswa. Jurnal Pendidikan Fisika, 1(2).

Regia, D., Suarsini, E., \& Lestari, S. R. (2016). Pengembangan multimedia interaktif sistem endokrin manusia berbasis guided inquiry untuk siswa kelas XI SMA Negeri 1 Lawang. SKRIPSI Jurusan Biologi-Fakultas MIPA UM.

Roviati, E. (2012). Pengembangan Model Pembelajaran Kooperatif Tipe Jigsaw Untuk Meningkatan Aktivitas Dan Hasil Belajar Biologi Dengan Pengantar Bahasa Inggris Pada Siswa SMA RSBI. Scientiae Educatia: Jurnal Pendidikan Sains, 1(1), 57-68.

Sanjaya, W. (2008). Kurikulum dan Pembelajaran: Teori dan Praktik Pengembangan Kurikulum Tingkat Satuan Pendidikan (KTSP). Penerbit Kencana: Jakarta.

Slavin, R. E. (2011). Instruction Based on Cooperative Learning. In R. E. Mayer \& P. A. Alexander (Eds.), Handbook of Research on Learning and Instructuin, 6(4) :344-360.

Tran, V. D., \& Lewis, R. (2012). The Effects of Jigsaw Learning on Students' Attitudes in a Vietnamese Higher Education Classroom. International Journal of Higher Education, $1(2), 9-20$.

Trianto. (2016). Mendesain Model Pembelajaran Inovatif - Progresif. Penerbit Kencana: Jakarta.

Yulaikah, M. (2013). Penerapan jigsaw untuk meningkatkan hasil belajar siswa sekolah dasar. E-Jurnal Dinas Pendidikan. Surabaya, 6. 